\title{
Perkembangan Motorik Kasar Anak Usia Dini pada Permainan Melempar dan Menendang Bola TK B 5-6 Tahun di Taman Kanak- Kanak Pembina Kabupaten Merangin
}

\author{
Lola Monika \\ Dosen STKIP Al-Azhar Diniyyah Jambi Indonesia \\ Correspondence email: ibuoyafariq@gmail.com
}

\begin{abstract}
This research is located in the country TK Negeri Pembina Kabupaten Merangin district which is motivated by the problem of groos motor development of children at play throwing and kicking ball. The study ured a qualitative approach to the determination of research subjects usiang snowball sampling technique. Technique of data collection is done by observasion, interview and documentation. data prensetation and verification/conlusion, while believe test data is done by extending the participation of, the accuary of obsevasion, triangulation and do the supervising consultant. The result showed that there were some children in TK domestic builder Merangin district who do not want follow the learning activites on groos motor skill in the game throwing and kicking a ball, abstracles children too quiet does not want to socialize on their friends, and also the old wold rather play alone than come play ball with his friends. As well as the child's parents did not want their children to participate in the learning activites throwing and kicking a ball game because parents fear that their children hit by the ball.
\end{abstract}

Keyword :groos motor development, game, throw and kick the ball

Abstrak. Penelitian ini berlokasi di TK Negeri Pembina Kabupaten Merangin, yang di latarbelakangi oleh masalah Perkembangan Motorik Kasar Anak Pada Permainan Melempar dan Menendang Bola. Penelitian ini menggunakan pendekatan kualitatif dengan penentuan subjek penelitian menggunakan teknik snowball sampling. Teknik pengumpulan data dilakukan dengan teknik observasi, wawancara, dan dokumentasi.Teknik analisis data meliputi reduksi data, penyajian data, dan verifikasi/penarikan kesimpulan, sedangkan uji keterpecayaan data dilakukan dengan perpanjang keikutsertaan, ketelitian pengamatan, trianggulasi dan melakukan konsultasi pembimbing. Hasil penelitian menunjukkan bahwa ada beberapa anak di TK Negeri Pembina Kabupaten Merangin tidak mau mengikuti kegiatan pembelajaran tentang motorik kasar pada permainan melempar dan menendang bola, kendalanya anak terlalu pendiam tidak mau bersosialisasi pada teman-temannya, dan juga anak lebih senang bermain sendiri dibandingkan ikut bermain bola bersama temannya. Dan juga orang tua si anak pun tidak ingin anaknya ikut dalam kegiatan pembelajaran permainan melempar dan menedang bola dikarenakan orang tua takut jika anaknya terkena pukulan bola.

Kata Kunci :Perkembangan motorik kasar, permainan, melempar dan menendang bola

\section{PENDAHULUAN}

Lingkungan belajar, baik di dalam maupun di luar mempengaruhi apa dan bagaimana anak belajar, Lingkungan yang mengundang, mendorong dan membantu anak bereksplorasi, bereksperimen, memanipulasi, benda dan alat main secara bermakna, menyenangkan, dan menantang kemampuan berfikir mereka membuat kegiatan pembelajaran menjadi semakin menyenangkan.

Piaget mengemukakan bahwa saat bermain anak tidak belajar sesuatu yang baru, tetapi mereka belajar mempratikkan mengkonsolidasikan keterampilan yang baru di peroleh, contohnya pada episode bermain peran yang dilakukan seorang anak bersama teman-temannya terjadi beberapa transformasi simbolis seperti pura-pura menggunakan balok sebagai telur.

Vygotsky juga percaya bahwa permainan adalah latar yang sangat baik untuk perkembangan kognitif, dia terutama tertarik pada aspek simbolik dan berpura-pura dari permainan, seperti ketika seorang anak menunggangi tongkat seolah-olah itu adalah kuda, bagi anak kecil situasi imajiner tersebut nyata, orang tua harus mendorong permainan imajiner seperti itu karena permainan tersebut mempercepat perkembangan kognitif anak khususnya pemikiran kreatif.

Vygotsky telah menyelesaikan suatu revolusi dalam psikologi perkembangan dia membuat pengertian mengenai perkembangan psikologi anak di tinjau dari proses terjadinya motif dari perkembangan dan 
Lola Monika, Perkembangan Motorik Kasar Anak Usia Dini pada Permainan Melempar dan Menendang Bola TK B 5-6 Tahun di Taman Kanak-Kanak Pembina Kabupaten Merangin

perubahan-perubahannya dari tahapan yang satu ketahapan yang secara singkat dapat dikatakan bahwa dia menggunakan dan memformulasikan peraturan-peraturan tentang perkembangan psikologi anak, ilmu psikologi yang dianutnya berdasarkan analisis filosofi yang mendalam, pokok-pokok pertanyaan yang diajukan Vygotsky adalah bagimana seorang manusia bisa melampaui sifat-sifat kebinatangannya dan bagaimana dia bisa mengembangkan dirinya menjadi manusia yang berbudaya dan berkarya, menurut Vygotsky manusia itu telah membentuk motif-motif baru dan kebutuhan-kebutuhan baru dalam proses perjalanan perkembangan manusia secara historis.

Kegiatan untuk meningkatkan perkembangan fisik motorik kasar anak dapat dilakukan melalui permainan dengan alat bantu atau tanpa alat, melempar dan menendang bola merupakan salah satu permainan yang dapat mengembangkan motorik anak. Selain itu kegiatan bermain melempar dan menendang bola dapat mempertinggi semua aspek pertumbuhan anak.

Berdasarkan pengamatan dilapangan yaitu di TK Negeri Pembina Kabupaten Merangin menunjukkan bahwa permaina yang di mainkan oleh anak usia 5-6 tahun khususnya dalam permainan melempar dan menendang bola belum memenuhi kiteria anak dalam menerapkan gerakan-gerakan dasar.

Adapun criteria anak dalam menerapkan gerakan-gerakan dasar :

1. Anak akan belajar dengan baik apabila kebutuha fsiknya terpenuhi serta merasa aman dan nyaman dalam lingkungan.

2.anak belajar terus menerus di mulai dari membangun pemahaman tentang sesuatu, mengeksplorasi lingkungan, menemukan kembali suatu konsep.

3. Anak belajar melalui interaksi sosial, baik dengan orang dewasa maupun dengan teman sebaya.

4. Minat dan ketentuan anak akan memotivasi belajar anak.

5. Perkembangan dan gaya belajar anak harus dipertimbangan sebagai perbedaan individu.

6. Anak belajar dari hal-hal yang sederhana sampai kompleks, dari yang konkret ke abstrak, dari yang berupa gerakan ke bahasa verbal, dan dari diri sendiri ke interaksi dengan orang lain.

Sering tampak bahwa anak usia dini senang bermain, dan senang dengan warna-warna cerah, bahkan warna yang mencolok, warna itu pula yang sering dijadikan cat dinding kelas mereka. Dilihat dari sejumlah anak asyik bermain petak umpet, menyusun balok bersama, menemukan anak yang asyik bermain balok, sementara yang lain bermain ular tangga, ada juga anak yang sibuk membolak-balik buku. Apa yang saksikan merupakan kegiatan pembelajaran ank usia dini. Mereka belajar sambil bermain, belajar melalui permainan atau bermain untuk belajar dan memperoleh pemahaman terhadap sesuatu.

Dengan bermain di Taman Kanak-kanak merupakan cara yang paling baik untuk menggembangkan kemampuan anak usia dini, sebelum sekolah bermain merupakan cara ilmiah anak untuk menentukan lingkungan, orang lain, dan dirinya sendiri. Pada prinsipnya bermain mengandung rasa senang dan lebih mementingkan proses dari pada hasilnya.

Berdasarkan Grand Tour hasil pengamatan di TK Negeri Pembina Kabupaten Merangin pada kegiatan permainan yang dilakukan di Out Door sekolah yang dilaksanakan di aula sekolah permainan melempar dan menendang bola, setiap ada kegiatan permainan yang berkenaan dengan perkembangan motorik seperti pada permainan melempar dan menendang bola, sebagian anak-anak kelas B dari TK Negeri Pembina di Kabupaten Merangin belum bisa terlaksana Karena dalam kegiatan permainan melempar dan menangkap bola anak tidak mau mengikuti permainan tersebut, hal ini disebabkan kegiatan permainan yang diadakan di luar kelas atau di aula sekolah, anak tidak mau mengikuti kegiatan permainan melempar dan menangkap bola dan orang tua anak tersebut tidak mau anaknya mengikuti kegiatan permainan tersebut dikarenakan orang tua mengingat keadaan anaknya yang tidak mau kalau terkena pukulan bola anak akan menangis dan juga orang tua takut anaknya terjatuh kelantai disebabkan permainan dilakukan diaula sekolah yang berlantaikan keramik, karena di TK Negeri Pembina Kabupaten Merangin memiliki halaman yang bisa terbilang kecil, sehingga orang tua tidak boleh anaknya untuk mengikuti kegiatan permainan melempar dan menendang bola. Maka dari itu kegiatan dalam bentuk permainan melempar dan menendang bola di TK Pembina kelas B yang di lakukan di halaman sekolah atau di aula sekolah yang di laksanakan seminggu sekali pada hari sabtu. 
Lola Monika, Perkembangan Motorik Kasar Anak Usia Dini pada Permainan Melempar dan Menendang Bola TK B 5-6 Tahun di Taman Kanak-Kanak Pembina Kabupaten Merangin

Studi pendahuluan atau Grand Tour yang telah peneliti lakukan melalui observasi di TK Negeri Pembina Kabupaten Merangin terdapat beberapa permasalahan dalam pembelajaran permainan melempar dan menendang bola dalam mengembangkan kemampuan motorik kasar anak, hal ini di karenakan :

1. Kurangnya partisipasi anak-anak di TK Negeri Pembina Kabupaten Merangin dalam pelaksanaan pembelajaran permainan melempar dan menendang bola, itu terlihat dari kegiatan anak pada saat pembelajaran berlangsung.

2. Ketidakbolehan orang tua pada anaknya untuk mengikuti pembelajaran mengenai perkembangan motorik kasar pada saat permainan melempar dan menendang bola.

3. Program pengembangan motorik kasar anak dalam pembelajaran permainan melempar dan menendang bola belum terlaksana dengan baik, itu terlihat masih ada anak yang tidak mau mengikuti kegiatan pembelajaran tersebut dikarenakan ada faktora kondisi dalam diri anak dan faktor dari luar diri anak.

Berdasarkan Grand Tour di atas maka dapat penulis membuat kesimpulan Grand Question sebagai berikut :(1) Bagaimana pelaksanaan pembelajaran melempar dan menendang bola belum terlaksana dengan baik. (2) Mengapa orang tua tidak memperbolehkan anaknya mengikuti pengembangan motorik kasar anak dalam pembelajaran permainan melempar dan menendang bola. (3) Faktor apa yang ada di dalam diri anak sehingga anak tidak mau mengikuti pembelajaran perkembangan motorik kasar anak pada permainan melempar dan menendang bola.

\section{LANDASAN TEORI}

\section{Aspek Perkembangan Motorik Kasar}

Motorik kasar adalah kemampuan gerak tubuh yang menggunakan otot-otot besar, sebagian besar atau seluruh tubuh anggota tubuh motorik di perlukan agar anak dapat duduk, menendang, berlari, naik turun tangga dan sebagainya.Keterampilan motorik kasar meliputi keterampilan otot-otot besar lengan, kaki, dan batang tubuh, seperti jalan dan melompat. Perkembangan motorik tergantung pada perkembangan syaraf dan otot, keterampilan motorik akan terjadi jika anak sudah mencapai kematangan, perkembangan motorik dapat diramalkan, oleh karena itu dapat dibuat sesuatu norma, yaitu kegiatan motorik tertentu dapat dilakukan pada usia tertentu, dapat perbedaan individual dalam laju perkembangan motorik.

Proses perkembangan anak usia dini pada perkembangan motorik kasar (1) Menunjukkan ketekunan fisik seperti : melempar bola yang berat, mengangkat sesuatu sambil duduk, memanjat peralatan manjat, tidak cepat lelah, melompat dengan satu kaki, melompat dengan dua kaki bersama-sama, menendang bola. (2) Bergerak dengan koordinasi dan keseimbangan seperti : menggulirkan bola ke tujuannya, menangkap bola dengan dua tangan, berlari dengan kontrol, meloncat dengan kontrol, menggerakkan badan di atas dibawah dan seputaran benda, melakukan lompat tali dengan kedua kaki bersama-sama.

Menurut Chaplin mengartikan perkembangan yakni 1) perubahan yang berkesinambungan dan progresif dalam organism, dari lahir sampai mati, 2)pertumbuhan, 3) perubahan dalam bentukdan dalam integrasi dari bagian-bagian jasmaniah ke dalam bagian-bagian fungsional, 4) kedewasaan atau kemunculan pola-pola asasi dari tingkah laku yang dipelajari. Dalam pandangan Montessori, perkembangan tidak terjadi dalam satu jenjang menanjak berkelanjutan (implikasi model ini adalah anak hanyalah seorang dewasa kecil) atau dalam cara konstan atau linear sejak lahir hingga dewasa.

Perkembangan motorik anak TK didasari pada aktivitas. Aktivitas anak usia TK 80\% menggunakan aktiviats jasmani atau fisik, pada usia 5-6 tahun anak dapat meloncat-loncat, merangkak dibawah meja atau kursi, memanjat, dapar melakukan gerakan-gerakan yang kasar dan halus dengan bekerja sama dalam koordinasi yang baik anak dapat mengadakan eksplorasi keliling yaitu manipulasi dengan benda-benda dan berbagai macam alat permainan.

Perkembangan motorik merupakan proses keterampilan dan pola gerakan yang dapat dilakukan anak, minsalnya dalam kemampuan motorik kasar anak belajar menggerakan seluruh tubuh kemudian metode yang digunakan adalah metode kegiatan yang dapat memacu semua kegiatan motorik kasar yang perlu dikembangkan anak seperti anak dapat belajar menendang bola dan sebagainya. Sedangkan perkembangan motorik kasar anak usia 5-6 tahun seperti berlari, dan langsung menendang bola, melompat-lompat dengan 
Lola Monika, Perkembangan Motorik Kasar Anak Usia Dini pada Permainan Melempar dan Menendang Bola TK B 5-6 Tahun di Taman Kanak-Kanak Pembina Kabupaten Merangin

kaki bergantian, melambungkan bola tenis dengan satu tangan dan menangkapnya dengan satu tangan, berjalan pada garis yang sudah di tentukan, mengayuhkan satu kaki kedepan atau kebelakang tanpa kehilangan keseimbangan. Prinsip perkembangan motorik kasar anak :

a. Anak usia TK sudah memiliki kemampuan melihat dengan fokus yang benar, sehingga guru dapat memberikan aktivitas melempar bola, dia telah memiliki kemampuan melihat bola dilempar kearahnya dan ditangkap oleh tangan, guru dapat menciptakan aneka aktivitas dengan menggunakan karakteristik ini.

b. Anak usia TK telah dapat melakukan serangkaian gerakan secara berkelanjutan minsalnya gerakan melempar, dan menendang.

c. Guru perlu memberikan relaksasi pada anak setelah mereka beraktivitas atau melakukan suatu gerakan.

d. Gerakan oposisi, gerakan ini perlu diperkenalkan pada anak, gerakan oposisi adalah gerakan seperti berjalan atau berlari dimana posisi tangan kanan di ayun ke depan di koordinasikan dengan langkah kaki ke depan, koordinasi ini dapat dilatihkan kepada anak dalam kegiatan baris-berbaris.

Anak usia5-6 tahun yang mulai memasuki masa preschoolmemiliki banyak keuntungan dalam fisikmotorik, sejalan dengan perkembangan fisik yang terjadi mereka dapat membuat tubuh melakukan apa yang mereka inginkan hal tersebut didukung oleh adanya perkembangan pada area sensoris dan motorik di konteks yang memungkinkan koordinasi yang lebih baik antara apa yang diinginkan anak dengan apa yang mampu dilakukannya.

Pada usia ini anak mulai memiliki koordinasi dan keseimbangan hampir menyerupai orang dewasa, perkembangan kemampuan yang membutuhkan koordinasi sebagian besar bagian tubuhnya, didukung dengan pertumbuhan otot dan tulang yang kuat, memungkinkan anak mampu melakukan hal-hal seperti meloncat, memanjat, berlari, menaiki sepeda roda tiga, serta berdiri dengan satu kaki selama lebih sepuluh detik, dia bahkan sudah memiliki kekuatan otot untuk melakukan hal-hal yang lebih menantang seperti jungkir bailk, bermain sepatu roda, bahkan bermain egrang. Tidak semua anak mengalami perkembangan yang sempurna sesuai dengan perkembangan usianya, ada banyak hal yang menjadi masalah dalam perkembangan motorik seorang anak.

Tabel. 1

Perkembangan Kemampuan Motorik Kasar Anak Usia 5-6 Tahun

\begin{tabular}{|l|l|}
\hline \multicolumn{1}{|c|}{ Kegiatan } & \multicolumn{1}{c|}{ Usia 5-6 tahun } \\
\hline Berlari & $\begin{array}{l}\text { a. Kemampuan berlari dan kontrol gerakan anak hampir menyerupai } \\
\text { orang dewasa } \\
\text { b. Anak dapat melakukan kemampuan ini (berlari dan kontrol } \\
\text { gerakan) dalam permainan. contoh : main kejar-kejaran } \\
\text { c. Anak dapat menggabungkan gerakan berlari dengan gerakan lain, } \\
\text { seperti jongkok dalam suatu permainan. contoh : main 'tap } \\
\text { jongkok'. }\end{array}$ \\
\hline Melompat & $\begin{array}{l}\text { Gerakan melompat yang dilakukan dapat digabungkan dengan } \\
\text { gerakan lain, minsalnya berlari lalu melompat sejauh kurang lebih } \\
60-70 \mathrm{~cm}\end{array}$ \\
\hline Melempar & $\begin{array}{l}\text { Dapat menendang dengan gerakan yang benar dengan cara } \\
\text { mengayunkan kaki kanan ke depan sambil menendang }\end{array}$ \\
\hline
\end{tabular}

Dalam dunia anak dan pendidikan anak usia dini sulit sekali mencari pengganti kegiatan yang sepadan dengan bermain, termasuk pembelajaran formal karena bagi anak usia dini bermain jauh lebih efektif mencapai tujuan dibandingkan dengan pembelajaran formal di kelas, pembelajaran memiliki lingkup yang sangat terbatas dan tidak dapat menyentuh tujuan yang multimak seperti dalam permainan, guru harus pandai memilih permainan yang dibutuhkan dan paling tepat menjadi sarana pembelajaran bermain juga menjadi prinsip pembelajaran di Taman kanak-kanak karena bermain merupakan cara yang paling baik 
Lola Monika, Perkembangan Motorik Kasar Anak Usia Dini pada Permainan Melempar dan Menendang Bola TK B 5-6 Tahun di Taman Kanak-Kanak Pembina Kabupaten Merangin

untuk mengembangkan kemampuan anak untuk menentukan lingkungan, orang lain, dan dirinya sendiri, pada prinsipnya bermain mengandung rasa senang dan lebih mementingkan proses daripada hasilnya.

\section{METODOLOGI PENELITIAN}

Penelitian ini membahas perkembangan motorik kasar anak usia dini melalui permainan melempar dan menangkap bola di Taman Kanak-kanak usia 5-6 di Taman Kanak-kanak Negeri Pembina Kabupaten Merangin dengan menggunakan pendekatan kualitatif dari sudut pandang pendidikan. Penelitian Kualitatif adalah penelitian yang pemecahan masalahnya dengan menggunakan data empiris.

Data penelitian adalah sesuatu yang diketahui atau di anggap, diketahui artinya sesuatu yang sudah terjadi sebagai fakta empiric ( bukti yang ditemukan secara empiris melalui penelitian). Adapun manfaat data adalah pertama untyk mengetahui atau memperoleh gambaran tentang sesuatu keadaan atau persoalan.Kedua untuk membuat keputusan atau memecahakan persoalan. Karena persoalan yang timbul itu ada penyebabnya, maka memecahakan persoalan maksudnya menghilangkan factor-faktor yang menyebabkan timbulnya persoalan tersebut, sehingga dengan demikian dia berfungsi sebagai : 1) Dasar penyusunan perencanaan dalam rangka memecahkan persoalan sebagai mana yang telah dirumuskan dalam persoalan, 2) Alat kontrol dalam mengembangkan laporan agar tidak bias dalam pelaksanaan sesuai perencanaan yang telah digariskan proposal, 3) Dasar analisis dan pembuatan laporan penelitian secara lengkap.

Didalam teknik dan pengumpulan data observasi atau pengamatan adalah kegiatan keseharian manusia dengan menggunakan pancaindra mata sebagai alat bantu utamanya selain pancaindra lainnya seperti telinga, penciuman, mulut, dan kulit. Dan wawancara digunakan untuk melengkapi data observasi yang diperoleh langsung oleh seorang peneliti dalam sitausi sosial, data ini adalah penguatan akademis empiris yang dilakukan melalui proses triangulasi oleh karena itu dapat saja terjadi wawancara tidak selamanya yang telah disiapkan sebab dapaat mengalir pada bagian-bagian yang tersentuh oleh panduan wawancara, tetapi terkait dengan informasi atau data yang dibutuhkan.

\section{HASIL DAN PEMBAHASAN}

Berdasarkan observasi dalam pelaksanaan pembelajaran mengenai permaian melempar dan menendang bola di Taman Kanak-kanak Negeri Pembina Kabupaten Merangin peneliti melihat dalam kegiatan pembelajaran berlangsung banyak anak yang hanya melihat temannya bermain, hal ini disebabkan karena masih ada anak yang kurang partisipasi atau tidak nyaman dengan pembelajaran permainan melempar dan menendang bola dan juga fisik anaak yang agak lemah kalau terkena pukulan bola anak akan menangis.

Dalam pelaksanaan permainan berlangsung guru mengatur posisi anak sesuai dengan permainan yang akan dilakukan di ruangan bermian. Media yang di pakai adalah adalah disesuaikan dengan tema yang dilakukan.Kemudian guru menjelaskaan dan menyampaikan materi tentang permainan melempar dan menendang bola dengan jelas kepada anak karena materi harus sesuai dengan pembelajaran. Perkembangan motoric anak memiliki fase yang berbeda-beda sesuai dengan rentang umur anak, pada fase yang dilalui anak akan mengalami kegiatan-kegaiatan motoric yang berbeda-beda pula. Pada fase perkembangan tersebut anak harus harusmendapatkan rangsangan yang lebih baik agar bisa melewati fase tersebut dengan mendapatkan hasil yang maksianal bagi pertumbuhan perkembangannya.

Pendidikan merupakan salah satu proses dimana seorang diberi sesuatu pembekalan dan muatan berupa pengetahuan serta pengalaman. Proses pemberian dan muatan berupa pengetahuan dan pengalaman tidak hanya dilakukan di TK, akan tetapi melalui pendidikan di dalam keluarga, agar anak-anak dapat memperoleh pembelajaran, pendidikan serta latihan-latihan sesuai dengan perkembangannya baik perkembangan serta jasmani maupun secara rohani. Oleh karena itu, peranan bimbingan belajar dari orang tua bagi siswa implementasi menganai perkembangan motoric kasar dalam permainan melempar dan menendang bola sangatlah penting karena berpengaruh bagi perkembangan si anak, oleh karena itu guru TK sebagai mediator tentunya memiliki peranan yang penting terhadap pengembangan motoric anak selain orang tua di rumah. 
Lola Monika, Perkembangan Motorik Kasar Anak Usia Dini pada Permainan Melempar dan Menendang Bola TK B 5-6 Tahun di Taman Kanak-Kanak Pembina Kabupaten Merangin

Pengamatan peneliti dilapangan bahwa implementasi mengenai perkembangan motorik kasar pada usia dini di TK Negeri Pembina Kabupaten Merangin ini adalah mengikuti pola tertentu seperti penerapan disiplin, tanggung jawab, dan sosial. Ini dibuktikan dengan peraturan yang disepakati bersama sebelum memulai kegaiatn bermain. Untuk memahami bagaimana partisipasi orang tua terhadap implementasi metode dalam mengenai perkembangan motorik. kasar anak melalui permainan melempar dan menendang bola anak usia dini.

Berdasarkan wawancara penulis dengan orang tua siswa dapat di ketahui bahwa ada sebagian orang tua yang bisa menempatkan diri sebagai pembimbing dan ada yang tidak, meskipun sebagiannya lagi kurang bisa untuk menempatkan diri sebagai pembimbing, orang tua tidak serta merta ikut membantu menyelesaikan masalah yang di hadapi anak, namun orang tua hanya menjadi mediator dan fasilitator serta pengawas dalam melaksanakan tuntunan belajar anak di rumah. Meskipun keinginan ini mendapatkan kendala di lembaga.

Observasi penulis di TK Negeri Pembina Kabupaten Merangin menemukan bahwa orang tua tidak memahami aspek dari perkembangan motorik pada anak-anak. Dikarenakan pada saat dirumah anak tidak diperbolahkan bermain diluar rumah untuk bermain dengan teman-teman sebayanya sehingga anak tidak mengenali lingkungan dan anak tidak dapat mengembangkan motoriknya, sehingga anak seperti kelihatan lemah tidak ingin melakukan kegiatan apa pun di luar rumah sehingga anak lebih memilih menonton TV di rumah seharian dibandingkan bermain dengan teman sebayanya di luar. Anak yang dibimbing oleh orang tuanya di rumah memiliki banyak kesempatan untuk mengembangkan motoriknya dalam bermain, keteladanan orang tua tidak melakukan bimbingan kepada anak setiap waktu pertumbuhan anak. Anak-anak sekarang memang perlu diatur dibatasi dan peraturan-peraturan dirumah memang harus ada aturan bagi anak-anak yang menggunakan waktu sebaik mungkin, supaya tidak ada waktu yang terbuang percuma.

Menurut guru TK Pembina Kabupaten Merangin bahwa beban mengajar yang di berikan memang tidak banyak, namun sangat menjadi beban pemikiran bagi guru itu sendiri untuk belajar sebelum ia mengajar. Sebenarnya guru adalah ujung tombak yang beradapan langsung dengan pengguna fasilitas sekolah (siswa) hendaknya dapats menyiapkan diri secara sendiri. Efektif dan efesien untuk menjawab kebutuhan dan tantangan yang ada. TK Negeri Pembina Kabupaten Merangin sebagai organisasi professional yang hasil dampaknya bagi masyarakat dapat ditentukan oleh professional guru sebagai agen perubahan dalam mencerdaskan siswa. Sehubugan dengan itu maka seorang guru harus memiliki kemampuan untuk melaksanakan tugasnya. Tenaga kerja seperti guru, kepala TK, penilik, pengawas dan tenaga kependidikan lainnya perlu memiliki professional agar jasa kependidikannya terdapat anak-anak optimal.

Salah satu tugas yang harus dilaksanakan oleh guru ialah memberikan pelayanan kepada para peserta didik atau anak didik yang selaras dengan tujuan pendidikan anak usia dini, namun guru TK Negeri Pembina Kabupaten Merangin masih kurang pengalaman belajar dan menyesuaikan kemampuan yang dimiliki dengan tuntunan kurikulum. Melalui bidang pendidikan dalam keseluruhan proses pendidikan guru merupakan faktor utama yang bertugas mendidik, guru memegang berbagai jenis peranan mau tidak mau harus dilaksanakannya sebagai seorang guru, dan guru harus bertanggung jawab atas hasil kegiatan belajar anak melalui interaksi belajar mengajar, guru merupakan faktor yang mempengaruhi berhasil tidaknya proses belajar dan karenannya guru menguasai materi yang akan di ajarkan, dengan kata guru harus mampu menciptakan situasi kondisi belajar yang sebaik-baiknya.

Berdasarkan observasi di TK Negeri Pembina Kabupaten Merangin dapat diketahui bahwa media yang berkaitan dengan pembelajaran perkembangan motorik kasar sangat minim sekali, guru tidak pernah mempelajari tentang perkembangan motorik kasar, guru di tuntut untuk dapat menguasai dan memahami pembelajaran dengan dibekali kompetensi-kompetensi dengan baik dan guru harus dapat menyukai apa yang diajarkan dan menyukai aktivitas mengajar sebagai profesi. Kurangnya pemahaman tenaga pendidik (guru) mengenal perkembangan motorik kasar anak yang sebenarnya di TK Negeri Pembina Kab. Merangin ini menjadikan suatu permasalahan dalam proses pembelajaran, meskipun selalu diadakan kegiatan pertemuan para tenaga pendidik pada khususnya dan pertemuan antar lembaga umum disetiap bulannya untuk membahas berbagai kegiatan pembelajaran di TK padahal dalam kegiatan pertemuan tersebut telah 
Lola Monika, Perkembangan Motorik Kasar Anak Usia Dini pada Permainan Melempar dan Menendang Bola TK B 5-6 Tahun di Taman Kanak-Kanak Pembina Kabupaten Merangin

diberikan berbagai pemahaman tentang bagaimana mengajarkan anak didik dengan tidak hanya terpaku dalam satu metode sebagaimana yang diungkapkan dalam wawancara dengan salah satu tenaga pendidik yang bernama bu Winda yang mengatakan bahwa " upaya guru untuk menjadi guru yang professional adalah dengan mengikuti berbagai kegiatan seminar, workshop serta pelatihan-pelatihan yang diadakan oleh Dinas pendidikan baik Provinsi maupun Kabupaten.

Berdasarkan hasil observasi dan wawancara peneliti dilapangan, guru dan Kepala TK telah mengupayakan agar guru-guru di TK Negeri Pembina Kabupaten Merangin ini tetap mendapatkan pelajaran agar dapat di terapkan di TK, Melalui seminar-seminar Wrokshop, dan pelatihan-pelatihan yang diadakan di Kabupaten maupun provinsi.

\section{SIMPULAN}

Hasil dari paparan pada bab di atas dapatlah disimpulkan bahwa 1) Motorik kasar anak usia dini berkembang melalui permainan melempar dan menendang bola. 2) kendala-kendala perkembangan motorik kasar anak dalam permainan melempar dan menendang bola di TK Negeri Pembina Kabupaten Merangin seperti :

a. Ketidak bolehan orang tua pada anaknya untuk mengikuti perkembangan motorik kasar pada permainan melempar dan menendang bola dikarenakan orang tua takut anaknya jatuh saat sedang bermian karena permainan yang dilakukan di aula sekolah yang berlantaikan keramik.

b. Saat permianan melempar dan menendang bola ada beberapa anak yang kurang mau partisipasi di sebabkan ada anak yang pendiam dan malas untuk bergerak dan dilihat dari fisik anak juga lemah.

c. Sebagian orang tua tidak mau anaknya mengikuti permainan melempar dan menendang bola karena takut bola mengenai anaknya sehingga orang tua lebih memilih anaknya untuk duduk diam melihat teman-temannya bermain bola.

d. Orang tua kadang tidak memahami keinginan anaknya sehingga apa yang harus dilakukan anakanak tidak diberikan kebebasan oleh orang tuanya dalam memilih kegiatan.

e. Ketidakpercayaan orang tua terhadap anaknya dalam mengikuti perkembangan motorik kasar.

f. Rendahnya partisipasi dan dukungan orang tua terhadap anaknya dalam perkembangan motorik kasar.

Yang dilakukan oleh guru TK Negeri Pembina Negeri Pembina Kabupaten Merangin dalam menstimulasikan perkembangan motorik kasar melalui permainan melempar dan menendang bola yaitu :

1. Mengikuti kegiatan seminar, pelatihan, dan workshop.

2. Guru sebagai mediator dan model dalam kegiatan perkembangan motorik.

3. Mengikuti kegiatan keguruan untuk membangun dan menambah wawasan.

4. Mempersiapkan diri sebelum melakukan kegiatan perkembangan motorik kasar.

5. Membuat lingkungan belajar yang merangsang dan menentang anak untuk mengembangkan potensi dalam perkembangan motorik kasar.

6. Guru berperan sebagai teman atau sahabat bagi anak.

7. Menjadi guru yang menyenangkan dan bertutur kata dengan baik.

\section{DAFTAR PUSTAKA}

Abdul Mujib Dan Jusuf Mudzakir, Ilmu Pendidikan Islam, Jakarta, Kencana Prenada Media, April 2010.

Ahmad Mudjab Mahalli, Buku Pintar Para Da'I, Surabaya, Duta Ilmu, Cetakan Kedua Belas, 2003

Al-Qur'an dan Tafsirnya, Departemen Agama Republik Indonesia Proyek Pengadaan Kitab Suci Al-Qur'an, Jakarta, CV Ferlia Citra Utama, 2005

Anita Yus, Penilaian Perkembangan Belajar Anak Taman Kanak-kanak, Jakarta, Kencana Prenada Media Group, Cetakan Ke-1, 2012

Burhan Bungin, PenelitianKualitatif komunikasi, Ekonomi, Kebijakan, Publik dan Ilmu Sosial Lainya, Jakarta, Kencana Prenada Media Group, November 2011.

Crain, Wiliam, Teori Perkembangan, Yogyakarta : Pustaka Pelajar 2007 
Lola Monika, Perkembangan Motorik Kasar Anak Usia Dini pada Permainan Melempar dan Menendang Bola TK B 5-6 Tahun di Taman Kanak-Kanak Pembina Kabupaten Merangin

Diane E Papalia DKK, Human Development (Psikologi Perkembangan), Jakarta, Kencana Prenada Group, Cetakan Ke-2, November 2010

Djawad Dahlan, Psikologi Perkembangan Anak Dan Remaja, Bandung, PT Remaja Rosdakarya, 2012

Elzabenth B Hurluck, Perkembangan Anak, Jakarta PT Gelora Aksara Pratama

Iriani Indri Hapsari, Psikologi Perkembangan Anak, Jakarta, PT Indeks, 2016

Janice J. Beaty, Observasi Perkembangan Anak Usia Dini, Jakarta, Kencana Prenadamedia Group, Cetakan Ke-1, September 2013

Juliansya Noor, Metodologi Penelitian (skripsi, tesis, Dirsentasi dan Karya Ilmiah), Jakarta, Prenada Media, Group, Cetakan ke-3 September 2009

Muhibbin Syah, Psikologi Pendidikan Dengan Pendekatan Baru, Bandung, PT Remaja Rosdakarya, Februari 2010

Muhktar Latif et al, Orientasi Baru Pendidikan Anak Usia Dini Teori dan Aplikasi, Jakarta : Kencana, 2013

Rini Hildayani dkk, Psikologi Perkembangan Anak 1-am12 PGTK2104/4 SKS Jakarta : Universsitas Terbuka, 2008

Sumadi Suryabrata, Psikologi Pendidikan, Jakarta, PT Rajagrafindo Persadaa, Maret 2012

Soemiarti Patmonodewo, Pendidikan Anak Presekolah, Jakarta, PT Rineka Cipta, Juli 2014

Sunarto dan Agung Hartono, Perkembangan Peserta Didik, Jakara Rineka Cipta Februari 2013

Trianto, Desain Pengembagan Pembelajaran Tematik Bagi Anak Usia Dini TK/RA dan Anak Usia Kelas Awal SD/MI, Kencana Prenada Media Group, Juni 2011

Zakiah Darajad, Metode Khusus Pengajaran Agama Islam, Jakarta, PT Bumi Aksara, April 2008

Jhon W, Santrock, Perkembangan Anak, Jakarta, PT Gelora Aksara Pratama, April 2007 